\title{
Model Pemberdayaan dan Pengembangan Potensi Sumber Daya Lokal Berkelanjutan pada Desa Kangkung Kecamatan Mranggen Kabupaten Demak
}

\author{
Stacia Reviany Mege ${ }^{1}$, Rianditha Eri Werdani², Nurul Imani Kurniawati², \\ Kholidin ${ }^{2}$ \\ 1,2 Universitas Diponegoro, Indonesia
}

\begin{abstract}
A B S T R A C T
MODEL OF EMPOWERMENT AND DEVELOPMENT OF LOCAL RESOURCE POTENTIAL IN KANGKUNG VILLAGE, MRANGGEN SUBDISTRICT, DEMAK REGENCY IN ORDER TO CONTINUOUSLY IMPROVING THE STANDARD OF LIVING OF COMMUNITIES. Kangkung Village is located in Mranggen Subdistrict, Demak Regency, Central Java and rich in natural resources and other potentials. However, the local potentials are not well utilized due to lack of funding, technology, skill, and knowledge of the communities. Some sectors such as farming or gardening have been the main source of income for most of the villagers even though the disparity between village and cities is increasing. The purpose of this community service is to empower the community to realize their potential and to take action and move together for the prosperity of all villagers. Methods used to obtain the objective were socialization and assistance. The result of the community service was the identification of problems, solutions, and potential in Kangung Village. Furthermore, the community realized that local resource potential does not rely on natural resources only but more to human resources that they are motivated to improve their potential. In conclusion, socialization and assistance are needed by the village to realize their potential and must be done continuously and the collaboration between the community and village administrators is highly necessary to improve the standard of living.

\begin{tabular}{lccc} 
Keywords: & $\begin{array}{l}\text { Community Development, } \\
\text { Development. }\end{array}$ & Community & Empowerment, Village \\
\hline Received: & Revised: & Accepted: & Available online: \\
23.04.2020 & 09.07 .2020 & 22.10 .2020 & 30.11 .2020 \\
\hline
\end{tabular}
\end{abstract}

Suggested citation:

Mege, S. R., Werdani, R. E., Kurniawati, N. I., \& Kholidin. (2020). Model pemberdayaan dan pengembangan potensi sumber daya lokal berkelanjutan pada Desa Kangkung Kecamatan Mranggen Kabupaten Demak. Jurnal Pengabdian Pada Masyarakat, 5(4), 954-962. https://doi.org/10.30653/002.202054.548

Open Access I URL: http://ppm.ejournal.id/index.php/pengabdian/article/view/548

${ }^{1}$ Corresponding Author: Program Studi Manajemen dan Administrasi Logistik, Sekolah Vokasi Universitas Diponegoro; Jl. Prof. Sudarto, SH, Tembalang, Semarang, Jawa Tengah, Indonesia. Email: staciareviany@live.undip.ac.id 


\section{PENDAHULUAN}

Menurut Pasal 78 UU Desa terdapat lima prioritas pembangunan desa yakni (a) peningkatan pelayanan dasar; (b) pembangunan dan pemeliharaan infrastruktur dan lingkungan; (c) pengembangan ekonomi pertanian berskala produktif; (d) pengembangan dan pemanfaatan teknologi tepat guna; (e) peningkatan kualitas ketertiban dan ketenteraman masyarakat desa. Prioritas pembangunan desa sering menemui berbagai kendala. Permasalah yang sering ditemui di desa pada umumnya berhubungan dengan kemiskinan yang dialami masyarakat dan masih kurang berkembangnya kehidupan masyarakat pedesaan karena keterbatasan akses permodalan, infrastruktur, teknologi; terbatasnya pelayanan sarana dan prasarana permukiman seperti air minum, sanitasi, dll; terbatasnya kapasitas kelembagaan untuk mendungkung peningkatan SDM, serta kesenjangan yang diakibatkan kurangnya keterkaitan antara kegiatan ekonomi perkotaan dan pedesaan.

Masyarakat desa yang selama ini bergantung pada kegiatan pertanian primer harus mulai melakukan diversivikasi lapangan pekerjaan agar bisa memberdayakan dan mengembangkan potensi yang ada di desa tersebut. Potensi suatu desa adalah suatu daya dan kemampuan yang dimiliki desa dan dapat dikembangkan dan merupakan faktor penentu keberhasilan pembangunan desa dan kesejahteraan masyarakatnya (Endah, 2020). Masyarakat Desa Kangkung Kecamatan Mranggen, Kabupaten Demak memiliki potensi sumber daya alam yang beraneka ragam sehingga membuat desa ini dipandang mampu menjadi desa mandiri. Dari sisi pertanian, Desa Kangkung memiliki potensi padi, jagung tembakau, palawija, ketela pohon, bawang merah, kacang merah. Sejumlah buah-buahan yang dapat ditemukan bertumbuh dengan baik di Desa Kangkung yakni rambutan dan durian. Memiliki sumber daya alam yang sedemikian rupa tidak menjamin kemakmuran masyarakat oleh karena perkembangan jaman yang menuntut adanya nilai tambah untuk setiap sumber daya. Dalam perkembangannya, sektor industri kreatif merupakan sektor yang tepat untuk memberdayakan sumber daya yang dimiliki desa (Suhariyanto, Zainal, dan Budiarta, 2018). Oleh karena itu, potensi tersebut perlu dikembangkan dan diberdayakan oleh aparatur desa dan terlebih masyarakatnya.

Pembangunan suatu desa merupakan suatu rangkaian yang tidak terpisahkan antara pemberdayaan pembangunan manusia, pembangunan yang berbasis sumber daya lokal dan tentunya pembangunan kelembagaan (Rangkuti, 2011). Dapat ditemukan berbagai model pengembangan desa yang disesuaikan dengan potensi desa tersebut. Untuk desa yang memiliki potensi wisata, seperti pada desa yang ada di Nusa Tenggara Timur yakni desa Feapopi, Kuli, dan Sotimori, model yang dikembangkan dikenal dengan Model Pengembangan Desa Wisata Berbasis Kearifan Lokal (Manteiro, 2016); selain itu disusun juga Model Desa Wisata Berbasis Pemberdayaan Masyarakat (Rochman, 2016). Pada Desa Pasuruhan, Cilacap, Jawa Tengah yang memiliki potensi peternakan berhasil mengembangkan Model Community Development (Suswanto, Handoko, \& Sabiq, 2013). Untuk mengembangkan potensi masyarakat diperlukan pendekatan dengan metode yang berbeda. Beberapa jenis pengembangan potensi masyarakat menurut Notoatmodjo (2010) adalah sebagai berikut: community leaders, community organization, community fund, community material, community knowledge, and community technology. 
Pengembangan dan pemberdayaan potensi desa adalah proses pembangunan dimana masyarakat berinisiatif untuk memilai proses kegiatan sosial untuk memperbaiki situasi dan kondisi diri sendiri melalui potensi yang dimiliki oleh desa. Terdapat dua hal yang menjadi unsur berkaitan yakni pemberdayaan masyarakat dan partisipasi masyarakat. Pemberdayaan masyarakat dilakukan dengan memberikan motivasi dan dorongan agar masyarakat mampu menggali potensi diri dan berani bertindak untuk memperbaiki kualitas hidupnya secara pribadi dan memperbaiki kehidupan sosial ekonomi masyarakat secara umum (Endah, 2020). Prinsip pemberdayaan masyarakat yang dikenal diantaranya win-win solution, co-creation, cofinancing, sustainability, dan research based community services. Menurut Notoadmodjo (2007), prinsip-prinsip pemberdaaan masyarakat adalah menumbuhkembangkan potensi masyarakat, mengembangkan gotong royong masyarakat, menggali kontribusi masyarakat, dan menjalin kemitraan dan desentralisasi. Sedangkan unsur yang kedua yakni adanya partisipasi masyarakat adalah mengenai adanya kegerakan yang timbul atas kehendak dan keinginan sendiri untuk memperbaiki kualitas hidup. Model pemberdayaan dan pengembangan potensi sumber daya lokal ini akan berfokus pada kombinasi antara dua hal yakni sumber daya lokal dan komunitas/masyarakat di Desa Kangkung sehingga dapat memaksimalkan setiap potensi yang ada untuk meningkatkan taraf hidup masyarakat.

Untuk mengidentifikasi masalah dapat dilakukan dengan pendekatan community based research yang dilakukan secara kualitatif dengan mengukurnya menggunakan indeks desa membangun sebagai indikator (Setyobakti, 2017) dan bisa juga dilakukan dengan wawancara langsung kepada aparatur desa. Model pemberdayaan dan pengembangan potensi sumber daya lokal pada Desa Kangkung ini akan berfokus pada tiga pokok permasalahan yang dihadapi desa tersebut yakni masalah sosial budaya, masalah ekonomi dan masalah geografis. Masalah sosial budaya diakibatkan oleh minimnya sarana dan prasarana di pedesaan sehingga sumber daya seperti tanaman yang siap untuk dipasarkan harus menumpuk dan mengalami penurunan kualitas yang pada akhirnya dapat berujung pada penurunan harga. Selain itu masalah sosial budaya juga dapat ditemui pada terbatasnya lapangan pekerjaan di pedesaan. Aktivitas usaha dan mata pencaharian utama masyarakat di daerah pedesaan adalah usaha pengelolaan atau pemanfaatan sumber daya alam yang secara langsung atau tidak langsung ada kaitannya dengan pertanian. Peluang usaha di sektor non-pertanian belum mendapat sentuhan yang memadai dan belum berkembang dengan baik.

Masalah sosial budaya pun berkaitan erat dengan masalah ekonomi, dimana masih terpusatnya aktivitas produksi pada pertanian. Kemungkinan dampak ekonomi karena instabilitas harga cukup besar dirasakan oleh penduduk Desa Kangkung. Selain itu meskipun mayoritas petani, namun tidak semua dari mereka memiliki lahan milik pribadi untuk mereka garap. Banyak diantaranya memiliki lahan kurang dari 0.5 hektar dan bahkan hanya berstatus petani penyewa dan hal tersebut berdampak pada kesejahteraan mereka. Di samping kedua masalah di atas, masalah geografis juga harus menjadi perhatian karena menyangkut akses dari desa ke kota yang akan mempengaruhi kesejahteraan masyarakat.

Adapun tujuan kegiatan pengabdian kepada masyarakat Program Studi Manajemen dan Administrasi Logistik Sekolah Vokasi Universitas Diponegoro pada 
tahun 2020 adalah membantu masyarakat memperoleh daya untuk mengambil keputusan dan menentukan tindakan yang akan dilakukan terkait dengan diri masyarakat dalam mendukung pemberdayaan potensi pengembangan desa masyarakat, termasuk mengurangi efek hambatan pribadi dan sosial dalam melakukan tindakan.

\section{METODE}

Pengabdian kepada masyarakat ini dilaksanakan di Desa Kangkung, Kecamatan Mranggen, Kabupaten Demak, Jawa Tengah dalam jangka waktu lima bulan mulai dari persiapan, pelaksanaan sampai kepada evaluasi. Adapun yang menjadi sasaran dari kegiatan pengabdian kepada masyarakat ini adalah warga Desa Kangkung yang diwakili tiga sampai lima orang dari setiap dukuh, dan perwakilan pengurus desa.

Metode yang digunakan dalam pengabdian kepada masyarakat ini disesuaikan untuk memfasilitasi masyarakat dalam menyelesaikan masalahnya. Metode pendidikan masyarakat yang berisi penyuluhan atau sosialisasi terhadap masyarakat dan aparatur desa diyakini bisa membantu meningkatkan pemahaman masyarakat terhadap materi yang diberikan. Evaluasi program pengabdian kepada masyarakat ditujukan dengan kriteria 1) kegiatan pelaksanaan untuk perwakilan masing-masing dukuh pada Desa Kangkung, dan 2) masing-masing dukuh mengirimkan tiga perwakilan pengurus aktif desa. Indikator pencapaian kegiatan yang dipakai untuk mengevaluasi kegiatan ini adalah keberhasilan kegiatan penyuluhan dan penerapan hasil penyuluhan dalam program nyata di desa.

Materi pengabdian kepada masyarakat sesuai dengan tema yang diangkat yakni Pemberdayaan dan Pengembangan Potensi Desa dengan Pemanfaatan Sumber Daya Lokal Dalam Rangka Peningkatan Taraf Hidup Masyarakat Secara Berkelanjutan. Memberdayakan dan mengembangkan potensi yang dimiliki oleh pedesaan baik sumber daya manusia maupun sumber daya alam, tidak terlepas dari upaya untuk menjadi desa mandiri. Kemandirian suatu desa dilihat dari kemampuannya untuk memenuhi kebutuhannya sendiri tanpa ada ketergantungan terhadap bantuan dari pemerintah, mempunyai kerjasama yang baik, memiliki sistem administrasi yang baik, serta pendapatan masyarakat yang cukup. Faktor-faktor yang akan mempengaruhi terbentuknya desa mandiri adalah:

1) Potensi Sumber Daya Manusia:

a) masyarakat desa mempunyai motivasi dan budaya yang tinggi

b) Mempunyai jiwa wirausaha yang kuat

c) Mempunyai kemampuan dan keterampilan tertentu yang mendukung pengembangan potensi lokal

2) Potensi Sumber Daya Alam

a) Potensi desa mempunyai daya saing untk dikembangkan

b) Pengelolaan potensi desa secara berkelompok oleh masyarakat

c) Skala usaha berbasis sentra yang dilakukan oleh masyarakat

3) Pasar

a) Produk yang dikembangkan masyarakat dibutuhkan pasar

b) Produk masyarakat mempunyai daya saing pasar 
4) Kelembagaan dan budaya lokal, pelaksanaan program didukung oleh kelembagaan desa yang menjunjung tinggi

Agar berjalan sinergis dan berkesinambungan Pengembangan Desa Mandiri dilakukan melalui:

1) Penciptaan lapangan kerja, pengurangan tingkat kemiskinan

2) Pengembangan program di pedesaan harus sejauh mungkin melibatkan peran serta semua masyarakat, dari awal sampai akhir.

3) Komoditas yang dikembangkan mengacu pada potensi yang dimiliki oleh desa tersebut dan layak untuk dikembangkan

4) Wilayah pengembangan Desa Mandiri tidak dibatasi oleh wilayah administratif suatu desa.

5) Pengertia desa dalam Desa Mandiri lebih mengacu pada kelayakan teknis dan sosial ekonomis, bukan wilayah administrasi

6) Kelembagaan berbasis budaya dan kearifan lokal

Materi selanjutnya yaitu mengenai manfaat yang akan dicapai desa mandiri yakni berkembangnya potensi desa untuk meningkatkan kesejahteraan masarakat di wilayahnya melalui penciptaan lapangan kerja; meningkatkan kegiatan usaha ekonomi dan budaya berbasis kearifan lokal di desa. Meningkatnya kemandirian desa dalam melaksanakan kegiatan pembangunan; dan menurunnya disparitas pembangunan wilayah antara desa dengan kota.

\section{HASIL DAN PEMBAHASAN}

\section{Gambaran Umum Lokasi Pengabdian}

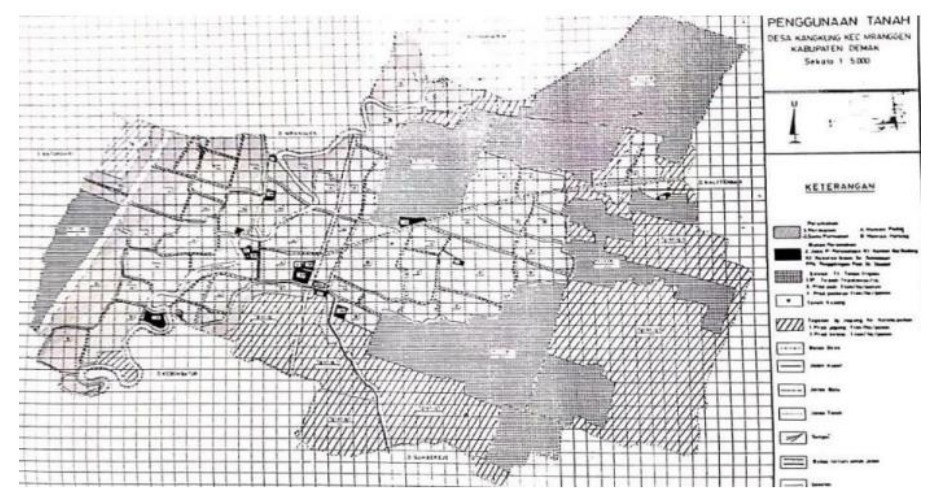

Gambar 1. Peta Wilayah Desa Kangkung

Desa Kangkung terletak di Kecamatan Mranggen, Kabupaten Demak, Jawa Tengah, Indonesia dan memiliki luas wilayah 5,15 $\mathrm{km}^{2}$. Wilayah Desa Kangkung sebagian besar digunakan untuk perumahan dan sebagian kecil dipergunakan untuk pertanian. Desa Kangkung dipimpin oleh Kepala Desa, Bpk. Kamsari dan didampingi oleh sekretaris dan perangkat desa. Dari segi demografis, $70 \%$ warga Desa Kangkung beragaman Islam, 11\% beragama Kristen Protestan, dan 17\% lainnya beragama Kristen Katholik, Hindu dan Budha. Desa Kangkung terbagi menjadi 6 (enam) RW (Rukun Warga) 
dengan jumlah penduduk mencapai 8.271 jiwa yang terdiri atas laki-laki 4.140 jiwa dan perempuan 4.131 jiwa.

Fasilitas yang dimiliki Desa Kangkung antara lain adalah Masjid Utama, Taman Kanak-kanak, Sekolah Dasar, SPM/MTs, SMA/MA, dan pertokoan. Desa Kangkung mempunyai potensi daerah yang baik dikarenakan mempunyai sumber daya yang cukup melimpah. Dari sisi pertanian potensi yang dimiliki antara lain padi, jagung, tembakau, palawija, ketela pohon, bawang merah, kacang merah, rambutan, durian, dll. Dari sisi masyarakat memiliki kemampuan untuk berkembang dengan dukungan kuat dari aparatur desa. Sedangkan dari sisi UMKM atau pelaku bisnis yang berkembang di Desa Kangkung, sangat beragam seperti makanan, minuman, mebel, industri sangkar burung, tekstil dan lainnya. Meskipun demikian potensi yang ada belum tergarap secara optimal.

\section{Mekanisme Pelaksanaan Kegiatan}

Secara keseluruhan, kegiatan pengabdian kepada masyarakat di Desa Kangkung dilakukan secara bertahap mulai dari survei lokasi pengabdian diikuti dengan pengumpulan potensi desa dan peran masyarakat, serta identifikasi permasalahan. Dari hasil identifikasi permasalahan ditemukan bahwa masyarakat belum sepenuhnya berperan aktif dalam program pengembangan, sehingga pada tahap awal dibutuhkan penyuuhan kepada masyarakat supaya masyarakat mempunyai kesadaran dan rasa kepekaan yang tinggi terhadap potensi besar yang dimiliki Desa Kangkung.

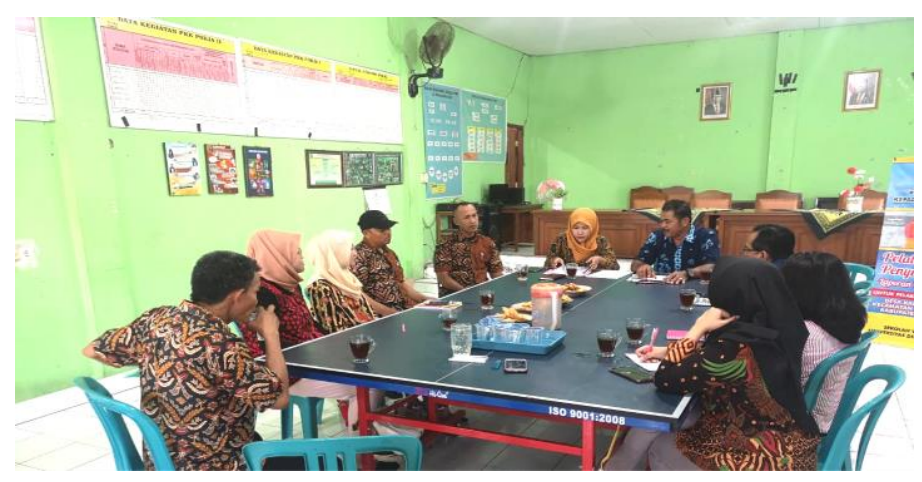

Gambar 2. Survei Lokasi dan Koordinasi dengan Aparatur Desa

Selanjutnya tim pengabdian menentukan metode apa yang tepat untuk dipakai, mempersiapkan materi, dan narasumber penyuluhan, serta koordinasi secara terusmenerus dengan aparatur Desa Kangkung. Langkah selanjutnya adalah kegiatan penyuluhan di Desa Kangkung. Mekanisme pelaksanaan kegiatan pengabdian kepada masyarakat dimulai dengan identifikasi permasalahan yang ada di Desa Kangkung, Kecamatan Mranggen, Kabupaten Demak, Jawa Tengah.

Penyuluhan dilaksanakan di Kantor Balai Desa selama satu hari pada Jumat 6 Maret 2020, pukul 09.00 - 14.00 WIB. Penyuluhan diikuti oleh 50 orang. Penyuluhan dilaksanakan dalam empat sesi. Pada sesi 1, Kepala Desa Kangkung, Bpk. Kamsari dan Sekretaris Desa Kangkung, Ibu Asrida memaparkan mengenai penyerapan dana badan usaha milik desa (bumdes) pada Desa Kangkung dan strategi yang digunakan agar potensi desa bisa dikembangkan dan diberdayakan secara aman dan optimal bagi perbaikan taraf hidup masyarakat. Selanjutnya pada sesi 2, narasumber pelatihan, 
Kholidin, S.Kom., M.Kom memaparkan mengenai faktor-faktor potensi apa saja yang bisa dilakukan untuk meningkatkan potensi Desa Kangkung dan prinsip apa saja yang harus dipegang teguh untuk pemberdayaan masyarakatnya. Sesi ketiga diisi dengan diskusi bersama perangkat desa dan perwakilan dari setiap dukuh yang mengikuti penyuluhan untuk menemukan solusi bersama dan meningkatkan partisipasi masyarakat Desa Kangkung sendiri. Sesi keempat atau sesi terakhir diisi dengan evaluasi kegiatan penyuluhan dan rencana pengabdian kepada masyarakat yang akan dilanjutkan kedepannya sebagai bentuk pendampingan untuk Desa Kangkung.

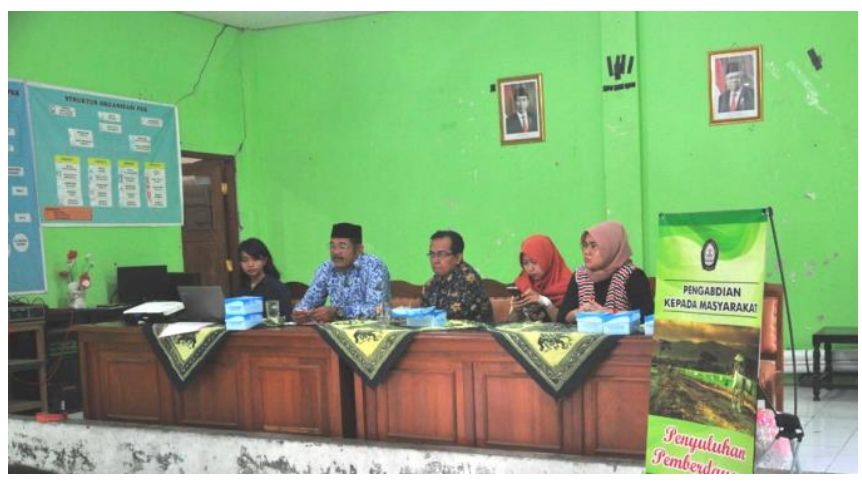

Gambar 3. Kegiatan Penyuluhan

Dari pembahasan oleh Kepala Desa dan Sekretaris Desa pada sesi 1, didapatkan hasil identifikasi permasalahan di Desa Kangkung yakni banyak potensi sumber daya alam yang belum dimanfaatkan secara optimal karena terkendala modal, teknologi, minimnya skill dan pengetahuan yang dimiliki masyarakat dan pelaku usaha. Pada sesi kedua, narasumber mencoba memfasilitasi setiap permasalahan yang berhasil diidentifikasi tersebut. Pengabdian kepada masyarakat ini berfokus pada memberikan penyuluhan awal kepada masyarakat untuk meningkatkan kesadaran masyarakat untuk berpartisipasi aktif dalam membangun kemandiriannya. Sehingga penyuluhan yang dilakukan oleh narasumber pun berfokus pada membangun kesadaran masyarakat untuk setiap permasalahan yang ada di Desa Kangkung.

Permasalahan ekonomi seperti pada masyarakat di Desa lain pada umumnya, yaitu permodalan, menjadi pembahasan pertama dari narasumber. Dalam paparannya narasumber menyampaikan bahwa sesungguhnya permodalan untuk usaha tersedia di berbagai tempat, baik itu dari institusi perbankan, pemerintahan, maupun swasta. Masyarakat perlu menggali informasi yang lebih mendalam dan mempersiapkan usahanya dengan baik. Karena suatu usaha akan lebih mudah mendapatkan kepercayaan oleh institusi dalam hal permodalan jika usaha tersebut memiliki kemampuan mengelola dan melaporkan dengan baik keuangan mereka (Kurniawati, Mege, Werdani, Aresteria, \& Kholidin, 2020). Sehubungan dengan rendahnya teknologi, dari hasil peninjauan tim pengabdian, dapat dilihat bahwa masyarakat sendiri memiliki keterbatasan dalam penggunaan teknologi modern. Sehingga narasumber berfokus kepada memberikan penyuluhan tentang pentingnya menguasai teknologi modern di era saat ini. Pemaparan berlangsung baik apalagi ditunjang oleh latar belakang pendidikan narasumber yang sangat tepat untuk menjelaskan tentang teknologi. 


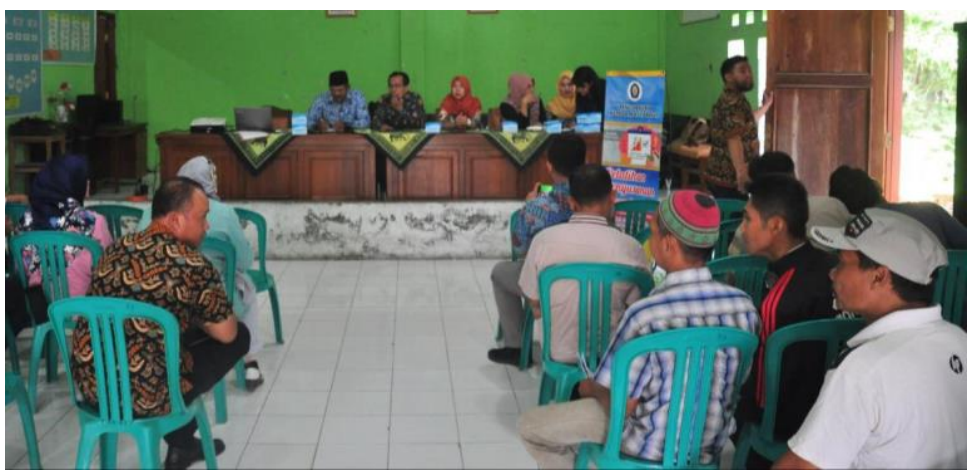

Gambar 4. Sesi Diskusi dalam Kegiatan Penyuluhan

Permasalahan skill dan kemampuan ditanggapi oleh narasumber dengan memperkenalkan media-media atau tempat dimana masyarakat bisa meningkatkan skill dan kemampuan mereka sesuai dengan minat yang dimiliki. Selain itu tim pengabdian juga akan memfasilitasi masyarakat Desa Kangkung yang ingin meningkatkan skill dan kemampuannya dengan cara melakukan pendampingan secara berkelanjutan. Dengan meningkatnya skill dan kemampuan, permodalan serta penggunaan teknologi yang baik, diharapkan masyarakat dapat memanfaatkan sumber daya alam dengan baik sehingga Desa Kangkung dapat menjadi desa mandiri dan memiliki hasil olahan sumber daya alam yang dapat diunggulkan di Kabupaten Demak, seperti pada desa-desa di daerah lainnya (Diartho, 2018).

Pada sesi ketiga dilakukan tanya jawab dengan masyarakat peserta penyuluhan. Pertanyaan yang diajukan sebagian besar berfokus tentang langkah konkrit apa yang harus diambil oleh masyarakat dan aparatur Desa Kangkung untuk memaksimalkan potensi lokal yang dimiliki. Sesi keempat ditutup dengan evaluasi kegiatan dan harapan dari masyarakat serta komitmen akan adanya pendampingan secara berkelanjutan dari Sekolah Vokasi Universitas Diponegoro untuk mendorong terciptanya Desa Kangkung yang mandiri yang mampu memberdayakan sumber daya lokalnya untuk kesejahteraan masyarakat desa.

\section{SIMPULAN}

Untuk membangun desa yang mandiri tidak hanya bergantung kepada sumber daya alam semata namun memerlukan masyarakat desa yang mandiri dan mampu bekerjasama untuk memaksimalkan potensi yang ada di desa tersebut. Peran pemerintah (pusat dan daerah) dalam pembangunan desa ditempatkan pada posisi yang tepat. Pemerintah diharapkan berperan dalam memberi motivasi, stimulus, fasilitasi, pembinaan, pengawasan, dan hal-hal yang bersifat bantuan terhadap pembangunan desa dalam aspek fisik.

Keterlibatan masyarakat sangat diperlukan dalam pembangunan desa. Karena proses pembangunan desa bukan hanya sebatas membangun sarana prasarana yang diperlukan, tetapi proses pembangunan desa memerlukan waktu yang panjang, banyak pengorbanan, dan bertalian dengan banyak pihak dalam masyarakat termasuk masyarakat di daerah pedesaan. 


\section{REFERENSI}

Diartho, H. C. (2018). Pengembangan wilayah perdesaan berbasis pada potensi sumber daya alam di Kabupaten Bondowoso. Ekonomikawan: Jurnal Ilmu Ekonomi dan Studi Pembangunan, 18(2), 102-122.

Endah, K. (2020). Pemberdayaan masyarakat: Menggali potensi lokal desa. Jurnal MODERAT, 6(1), 135-143.

Kurniawati, N. I., Mege, S. R., Werdani, R. E., Aresteria, M., \& Kholidin. (2020). Pemberdayaan umkm melalui pelatihan penyusunan laporan keuangan untuk umkm di desa Kangkung, Kecamatan Mranggen, Kabupaten Demak. Edupreneur: Jurnal Pengabdian Kepada Masyarakat Bidang Kewirausahaan, 3(1), 1-6.

Manteiro, M. C. B. (2016). Model pengembangan desa wisata berbasis kearifan lokal sebagai strategi pengentasan kemiskinan di Kabupaten Rote Ndao Nusa Tenggara Timur. Jurnal Bisnis \& Manajemen, 2(2), 93-101.

Notoatmodjo, S. (2007). Promosi kesehatan dan ilmu perilaku. Jakarta: Rineka Cipta.

Notoatmodjo, S. (2010). Promosi kesehatan teori dan aplikasi. Jakarta: Rineka Cipta.

Rangkuti, P. A. (2011). Komunikasi pembangunan dan mekanisme pertanian. Bogor: IPB Press.

Rochman, N. (2016). Model pengembangan desa wisata berbasis pemberdayaan masyarakat. Jurnal Equilibria Pendidikan, 1(1), 59-70.

Setyobakti, M. H. (2017). Identifikasi masalah dan potensi desa berbasis Indek Desa Membangun (IDM) di desa gondowangi kecamatan wagir Kabupaten Malang. WIGA: Jurnal Penelitian Ilmu Ekonomi, 7(1), 1-14.

Suhariyanto, J., Zainal, A., \& Budiarta, K. (2018). Pemberdayaan sumber daya lokal dalam pengelolaan sektor industri kreatif di Kecamatan Banda Sakti Kota Lhokseumawe: Studi kualitatif atas peran corporate social responsibility (CSR) PT. Pertamina (persero) marketing operation region (MOR) i-terminal bahan bakar minyak (TBBM) Lhokseumawe. Jurnal Pengabdian Kepada Masyarakat, 24(3), 792-797.

Suswanto, B., Handoko, W., \& Sabiq, A. (2013). Model community development sebagai strategi pemberdayaan berbasis kearifan lokal. Jurnal Review Politik, 3(2) 298-312.

Undang-undang Republik Indonesia Nomor 6 Tahun 2014 Tentang Desa.

\section{Copyright and License}

This is an open access article distributed under the terms of the Creative Commons Attribution 4.0 International License, which permits unrestricted use, distribution, and reproduction in any medium, provided the original work is properly cited.

C 2020 Stacia Reviany Mege, Rianditha Eri Werdani, Nurul Imani Kurniawati, Kholidin. 